\title{
CRITICAL PERIOD OF WEED COMPETITION IN TRANSPLANT AUS RICE CV. BRRI dhan27 UNDER NON-SALINE AGRO-ECOSYSTEM
}

\author{
M. T. Rahman, S. Ahmed, N. J. Lipi, M. H. Rashid and M. I. Hoque ${ }^{1}$ \\ Department of Agronomy, Patuakhali Science and Technology University, Patuakhali, Bangladesh, \\ ${ }^{1}$ Department of Environmental Science, Bangladesh Agricultural University, Mymensingh, Bangladesh \\ Corresponding author: trahman302@gmail.com
}

Key words: Critical period, weed competition, transplant Aus, BRRI dhan27

\begin{abstract}
A study was conducted to determine the critical period of weed competition in transplant Aus rice for var. BRRI dhan27. Among the treatments, weed free condition, competition of weed for first $10,20,30,40,50,60$ and 70 days and weed free later on, unweeded condition, one weeding at 20 days after transplanting and one weeding at 40 days after transplanting, the unweeded control plots showed the poor performance result in case of maximum parameters where grain yield was reduced the highest percentage (38.54\%). On the basis of cost benefit ratio it was observed that the critical period of crop weed competition extended up to 30 days after transplanting of aus var. BRRI dhan27.
\end{abstract}

\section{Introduction}

Rice is one of the most important staple foods for more than half of the world's population (IRRI, 2006) and influences the livelihoods and economies of several billion people. In Asia, more than $80 \%$ of the people live on rice, and their primary food security is entirely dependent on the volume of rice produced in this part of the world (Kabir, 2006). It is estimated that $40 \%$ of more rice production will be required by 2030 to satisfy growing demand with no increases in cropping areas (Khush, 2005).

Weeds are at present the major biotic constraint to increase rice production world wide (Zhang, 1996). About 33\% of this loses are caused due to weeds alone (Mukherjee and Singh, 2005). The yield losses due to uncontrolled weed growth in lowland and upland rice ranged from 12 to 81\% (Chopra and Chopra, 2003; Mukherjee and Singh, 2005). Normally the loss in rice yield ranges between $15-20 \%$ yet in severe cases the yield losses can be more than 50\% depending upon the species and intensity of weeds (BRRI, 2006). To develop a comprehensive control program for the weed, it is important to know its critical period of competition in transplant rice. The critical period of weed competition depends on several factors like species of weed, life time duration of crops, climatic factors, crop species, environmental factors etc. Critical period of weed control is an integral part of integrated weed management (IWM) and can be considered the first step to design weed control strategy (Anonymous, 2003). In general critical period of crop weed competition is throughout in direct seeding situation and in transplanted it vary from 15 to 45 days (Singh and Bhan, 1988). The most critical period for competition between rice and weeds is when the rice is in the vegetative phase and the yield components of rice are being differentiated (Mukherjee and Singh, 2003). Though critical period of weed-crop competition is an important component of weed management technology package for any crop but for aus variety BRRI dhan27 it has not been investigated to find out the critical period of weed competition in transplant Aus rice cv. BRRI dhan27.

\section{Materials and Methods}


Rahman et al.

The study was conducted at the field Laboratory of the Department of Agronomy, Patuakhali Science and Technology University, Patuakhali during the period of April to August 2012. Geographically, the Patuakhali Science and Technology University is situated at $20^{\circ} 20^{\prime \prime} \mathrm{N}$ latitude and $90^{\circ} 20^{\prime \prime} \mathrm{E}$ longitude. It belongs to the Agro Ecological Zone (AEZ)-13 named Ganges Tidal Flood Plain. The experimental site was about $1.5 \mathrm{~m}$ above the sea level. The field of the experimental site was characterized by Non calcareous Grey Floodplain soil with silty clays. It was well drained and medium high. The soil was mildly alkaline, non-saline, loam in texture and having soil $\mathrm{P}^{\mathrm{H}}$ ranges from 5.50 to 6.50 . Organic matter content was low (1.1\%) (SRDI, 2005). The experiment was laid out in a randomized complete block design with three replications and eleven treatments as: $T_{1}=$ Weed free condition, $T_{2}=$ Competition of weed for first 10 days and weed free later on, $\mathrm{T}_{3}=$ Competition of weed for first 20 days and weed free later on, $\mathrm{T}_{4}=$ Competition of weed for first 30 days and weed free later on, $\mathrm{T}_{5}=$ Competition of weed for first 40 days and weed free later on, $\mathrm{T}_{6}=$ Competition of weed for first 50 days and weed free later on, $\mathrm{T}_{7}$ $=$ Competition of weed for first 60 days and weed free later on, $\mathrm{T}_{8}=$ Competition of weed for first 70 days and weed free later on, $\mathrm{T}_{9}=$ Unweeded condition, $\mathrm{T}_{10}=$ One weeding at 20 days after transplanting (DAT) and $\mathrm{T}_{11}=$ One weeding at $40 \mathrm{DAT}$. The area of a unit plot was $4 \mathrm{~m} \times 2.5 \mathrm{~m}$.

The sprouted seeds were sown in the prepared seed beds on $5^{\text {th }}$ April, 2012. The seedlings were transplanted in the main field @ 2 seedlings hill $^{-1}$ with $20 \mathrm{~cm} \times 15 \mathrm{~cm}$ spacing on $30^{\text {th }}$ April, 2012. Fertilizers were applied @ 168 g Urea, 60 g TSP, 30 g MoP, 17 g Gypsum and 5 g ZnSo 4 to the plots. The whole amount of fertilizers except $\mathrm{N}$ was applied before final land preparation. Urea was top dressed @ $56 \mathrm{~g}$ in three equal splits at 15, 30 and 45 days after transplanting. Proper crop protection measures were taken during the entire course of crop production. Weeds were collected at every 10 days interval according to the treatments mentioned. Number of weed plant of each species in the unit plot was counted with the help of a plant counter. The intensity of infestation of each species of weed was calculated as the number of weed stands per unit area divided by the number of hills per unit area. Three weed sample plot ${ }^{-}$

${ }^{1}$ were collected at the time of weeding. The plant counter was placed at random in the unit plot and all the weeds within each $1 \mathrm{~m}^{2}$ were uprooted, dried first in the sun and thereafter, 24 hours in an electric oven maintaining a constant $105^{\circ} \mathrm{C}$. After drying weeds weight of each sample was measured and expressed in $\mathrm{g} \mathrm{m}^{-2}$. Three weed sample plot ${ }^{-1}$ were collected at the time of harvesting. The crop of all plots was harvested on 3 July 2012. Crop and yield contributing were also recorded.

\section{Results and Discussion}

Seven species of weeds under four different families were found in the experimental field. Three species belonged to the family Cyperaceae, two from Gramineae and one from each of Onagraceae and Pontederiaceae (Table 1). Among those weed species, Cyperus difformis L., Jussiaea decurrens (Watt.) DC. Cynodon dactylon (L.) Pers. were predominated, and constituted about $84 \%$ of the total weed vegetation. Only Cyperus difformis L. constituted 63.82 percent of total weed infestation and it was followed by Jussiaea decurrens (Watt.) DC. (11.40 percent). In total 14.26 weeds competed against one hill of rice of which 10.16 belonged to the family Cyperaceae, 1.88 belonged to the Gramineae family and rest small portion was belonging to other two family. Thirteen types of weeds were found in direct seeded and transplanted aus rice as affected by method of planting and weeding regime by Sarker et al. (2002). Individually the highest intensity of weed infestation $\left(9.09 \mathrm{hill}^{-1}\right)$ was recorded in Cyperus difformis L. Fimbristylis miliacea (L.) Vahl. showed the lowest intensity and numerically it was only 0.38 weeds hill ${ }^{-1}$. Jussiaea decurrens (Watt.) DC. and Cynodon dactylon (L.) Pers. was produced in an intensity of 1.63 and 1.22 weeds hill $^{-1}$. In case of weed population per square meter space total 456 weeds were found $\mathrm{m}^{-2}$ and the highest and lowest number of weeds belonged to the family Cyperus difformis L. and Fimbristylis miliacea (L.) Vahl. respectively as percent of total weed vegetation and intensity of weed infestation at weeding. In a study Ahmed et al. (1986) found that the principal weeds were Monochlora vaginalis, Scirpus mucrontus and Cyperus iria in case of BR3 cultivation in Aus season. In another study in case of direct seeded upland rice cultivation Cyperus rotundus and Echinochloa crusgalli 
Critical Period of Weed Competition in Transplant Aus Rice

was the principal weed (Mamun et al., 1986). Mercado (1979) found that competition of Echinochloa crusgalli was found to be the highest at a density of 20 plants $\mathrm{m}^{-2}$ within the critical period of crop-weed competition. This difference might be due to climatic change, varietal change and other cultural management.

Table 1. Infested weed species and their population in transplant Aus rice cv. BRRI dhan27

\begin{tabular}{l|l|l|l|c|c|c}
\hline & \multicolumn{2}{c|}{ Name of weeds } & \multirow{2}{*}{ Family } & $\begin{array}{c}\text { Weed } \\
\text { populatio } \\
\text { Local Name }\end{array}$ & $\begin{array}{c}\text { \% of } \\
\text { total } \\
\text { weed }\end{array}$ & $\begin{array}{c}\text { Intensity } \\
\text { of weed } \\
\text { (hill }\end{array}$ \\
\hline Sobuj nakful
\end{tabular}

The weed population increased gradually from the competition of weed for first 10 to 60 days and weed free later on. The highest (598.00) weed population was found in $T_{7}$ (competition of weed for first 60 days and weed free later on) and the lowest one (77.00) was found in $T_{2}$ ( for first 10 days and weed free later on). During harvesting time no weed was found in the experimental plot as the plots were kept weed free after every weeding treatment (Table 2). The highest (498.30) number of weeds were found in the plots which were kept unweeded $\left(T_{9}\right)$ and the lowest (288.70) was found in $T_{11}$ (One weeding at 40 DAT).

All the treatments had significant effect on weeds dry weight $\mathrm{m}^{-2}$ at weeding. Treatment $\mathrm{T}_{7}$ produced the highest (254.20 g) weeds dry weight at weeding whereas $\mathrm{T}_{2}$ produced the lowest $(6.54 \mathrm{~g})$. The treatments $\mathrm{T}_{9}$ and $\mathrm{T}_{10}$ gave the highest (204.20 g) and the lowest (144.30 g) dry weight of weeds. Similar result was found by Sarker et al. (2002). On average 33.8\% weed dry weight was reduced due to competition from Aus rice (Karim, 2000).

Table 2. Effect of duration of weed competition on the population and dry matter production of weeds in cultivation of transplant Aus rice cv. BRRI dhan27

\begin{tabular}{c|ccc|c}
\hline \multirow{2}{*}{ Treatments } & \multicolumn{2}{|c|}{ Weeds population $\left(\mathrm{m}^{-2}\right)$} & \multicolumn{2}{c}{ Weeds dry weight $\left(\mathrm{m}^{-2}\right)$} \\
\cline { 2 - 5 } & At weeding & At harvest & At weeding & At harvest \\
\hline $\mathrm{T}_{1}$ & $0.00 \mathrm{j}$ & $0.00 \mathrm{~d}$ & $0.00 \mathrm{i}$ & $0.00 \mathrm{~d}$ \\
$\mathrm{~T}_{2}$ & $77.00 \mathrm{i}$ & $0.00 \mathrm{~d}$ & $6.54 \mathrm{~h}$ & $0.00 \mathrm{~d}$ \\
$\mathrm{~T}_{3}$ & $152.00 \mathrm{~h}$ & $0.00 \mathrm{~d}$ & $7.69 \mathrm{~h}$ & $0.00 \mathrm{~d}$ \\
$\mathrm{~T}_{4}$ & $218.00 \mathrm{~g}$ & $0.00 \mathrm{~d}$ & $51.84 \mathrm{f}$ & $0.00 \mathrm{~d}$ \\
$\mathrm{~T}_{5}$ & $361.00 \mathrm{~d}$ & $0.00 \mathrm{~d}$ & $147.30 \mathrm{e}$ & $0.00 \mathrm{~d}$
\end{tabular}


Rahman et al.

\begin{tabular}{ccccc}
$\mathrm{T}_{6}$ & $415.00 \mathrm{~b}$ & $0.00 \mathrm{~d}$ & $168.60 \mathrm{~b}$ & $0.00 \mathrm{~d}$ \\
$\mathrm{~T}_{7}$ & $598.00 \mathrm{a}$ & $0.00 \mathrm{~d}$ & $254.20 \mathrm{a}$ & $0.00 \mathrm{~d}$ \\
$\mathrm{~T}_{8}$ & $398.00 \mathrm{c}$ & $0.00 \mathrm{~d}$ & $162.90 \mathrm{c}$ & $0.00 \mathrm{~d}$ \\
$\mathrm{~T}_{9}$ & $0.00 \mathrm{j}$ & $498.30 \mathrm{a}$ & $0.00 \mathrm{i}$ & $204.20 \mathrm{a}$ \\
$\mathrm{T}_{10}$ & $287.00 \mathrm{f}$ & $311.70 \mathrm{~b}$ & $48.31 \mathrm{~g}$ & $144.30 \mathrm{c}$ \\
$\mathrm{T}_{11}$ & $332.00 \mathrm{e}$ & $288.70 \mathrm{c}$ & $158.40 \mathrm{~d}$ & $165.20 \mathrm{~b}$ \\
\hline $\operatorname{LSD}_{(0.05)}$ & 0.69 & 1.55 & 3.19 & 2.94 \\
\hline
\end{tabular}

Different treatments had significant effect on the plant height of transplant Aus rice cv. BRRI dhan27. Numerically the plots which were kept weed free for whole the cultivation period $\left(T_{1}\right)$ gave the highest $(138.8 \mathrm{~cm})$ plant height and it was followed $(136.1 \mathrm{~cm})$ by 10 days for weed competition. On the other hand, the plots which were allowed for competition of weed for first 60 and 70 days; and the plots which were weeded only once at 40 days after transplanting (DAT) gave the lower plant height than others (fig. 1). Perera et al. (1992) and Sultana (2000) also found similar reduction on rice plant height due to competition of E. crusgalli.

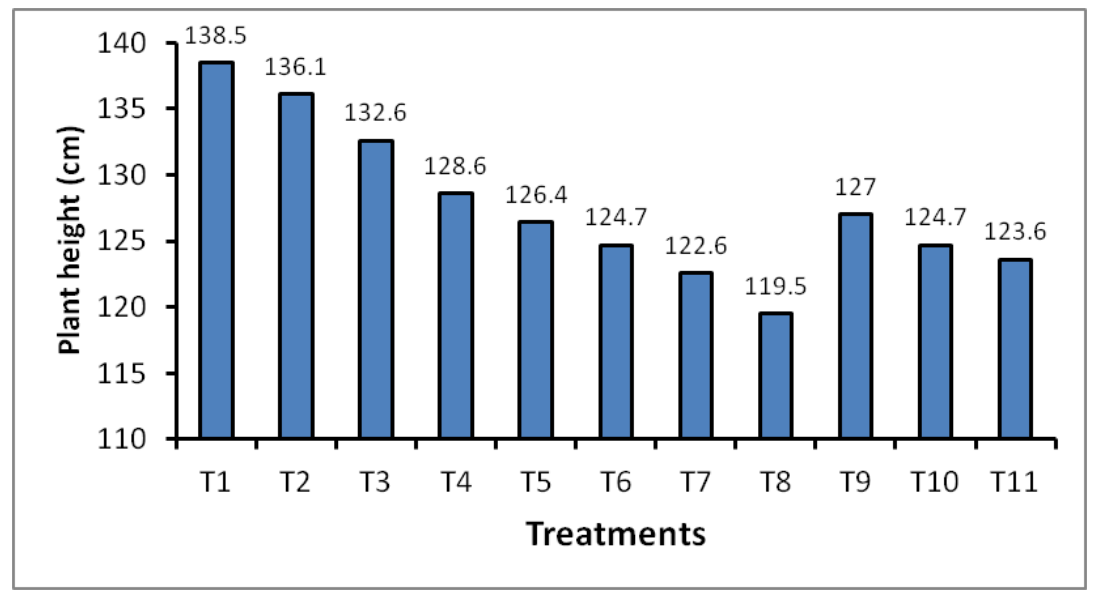

Fig. 1. Effect of duration of weed competition on plant height of transplant Aus rice cv. BRRI dhan27 $\left(\mathrm{LSD}_{(0.05)}=4.67\right)$

All the plots except those were kept unweeded $\left(T_{9}\right)$ for the entire cultivation period showed statistically at par in terms of panicle length. Treatments $T_{1}$ to $T_{4}$ produced higher panicle length than others where the longest $(24.14 \mathrm{~cm})$ panicle was produced where kept weed free throughout the cropping period $\left(\mathrm{T}_{1}\right)$. The plots in which first weeding were done after 40, 50, 60 and 70 days after transplanting and unweeded throughout the cropping period gave lower number of total tillers than others (Table 3).

Table 3. Effect of duration of weed competition on the yield contributing characters of transplant Aus rice cv. BRRI dhan27

\begin{tabular}{c|c|c|c|c|c}
\hline Treatments & $\begin{array}{c}\text { Panicle } \\
\text { length } \\
(\mathrm{cm})\end{array}$ & $\begin{array}{c}\text { Total tillers } \\
\text { hill }^{-1} \\
(\text { No. })\end{array}$ & $\begin{array}{c}\text { Filled grains } \\
\text { panicle }^{-1} \\
(\text { No. })\end{array}$ & $\begin{array}{c}\text { Unfilled grains } \\
\text { panicle } \\
(\text { No. })\end{array}$ & $\begin{array}{c}\text { 1000-grain } \\
\text { weight } \\
(\mathrm{g})\end{array}$ \\
\hline $\mathrm{T}_{1}$ & $24.14 \mathrm{a}$ & $11.09 \mathrm{a}$ & $108.0 \mathrm{a}$ & $16.72 \mathrm{a}$ & $31.55 \mathrm{a}$ \\
$\mathrm{T}_{2}$ & $23.90 \mathrm{ab}$ & $10.75 \mathrm{a}$ & $104.7 \mathrm{ab}$ & $14.46 \mathrm{~b}$ & $31.55 \mathrm{a}$ \\
$\mathrm{T}_{3}$ & $23.77 \mathrm{abc}$ & $10.82 \mathrm{a}$ & $101.4 \mathrm{bc}$ & $10.56 \mathrm{~d}$ & $31.58 \mathrm{a}$ \\
$\mathrm{T}_{4}$ & $23.10 \mathrm{bcd}$ & $9.557 \mathrm{~b}$ & $98.13 \mathrm{c}$ & $14.60 \mathrm{~b}$ & $31.22 \mathrm{ab}$ \\
$\mathrm{T}_{5}$ & $22.84 \mathrm{cde}$ & $8.837 \mathrm{c}$ & $98.54 \mathrm{c}$ & $9.493 \mathrm{e}$ & $31.54 \mathrm{a}$ \\
$\mathrm{T}_{6}$ & $22.61 \mathrm{def}$ & $8.820 \mathrm{c}$ & $92.11 \mathrm{~d}$ & $16.49 \mathrm{a}$ & $31.00 \mathrm{abc}$ \\
\hline
\end{tabular}


Critical Period of Weed Competition in Transplant Aus Rice

\begin{tabular}{cccccc}
\hline $\mathrm{T}_{7}$ & $22.24 \mathrm{def}$ & $8.297 \mathrm{~cd}$ & $84.40 \mathrm{e}$ & $10.46 \mathrm{~d}$ & $30.77 \mathrm{bcd}$ \\
$\mathrm{T}_{8}$ & $21.65 \mathrm{f}$ & $8.543 \mathrm{~cd}$ & $78.31 \mathrm{f}$ & $12.25 \mathrm{c}$ & $30.46 \mathrm{~cd}$ \\
$\mathrm{~T}_{9}$ & $19.14 \mathrm{~g}$ & $8.003 \mathrm{~d}$ & $74.42 \mathrm{~g}$ & $14.26 \mathrm{~b}$ & $30.15 \mathrm{~d}$ \\
$\mathrm{~T}_{10}$ & $22.04 \mathrm{ef}$ & $9.647 \mathrm{~b}$ & $84.84 \mathrm{e}$ & $7.710 \mathrm{f}$ & $30.73 \mathrm{bcd}$ \\
$\mathrm{T}_{11}$ & $21.90 \mathrm{ef}$ & $9.650 \mathrm{~b}$ & $86.75 \mathrm{e}$ & $14.60 \mathrm{~b}$ & $30.53 \mathrm{~cd}$ \\
\hline $\mathrm{LSD}_{(0.05)}$ & 1.01 & 0.65 & 3.56 & 0.64 & 0.66 \\
\hline
\end{tabular}

The plots which were kept weed free throughout the whole cultivation period, and the plots in which first weeding were done at 10,20 , and 30 DAT i.e. $\mathrm{T}_{1}$ to $\mathrm{T}_{4}$ gave statistically higher number (9.865-10.37) of effective tillers (Fig. 2).

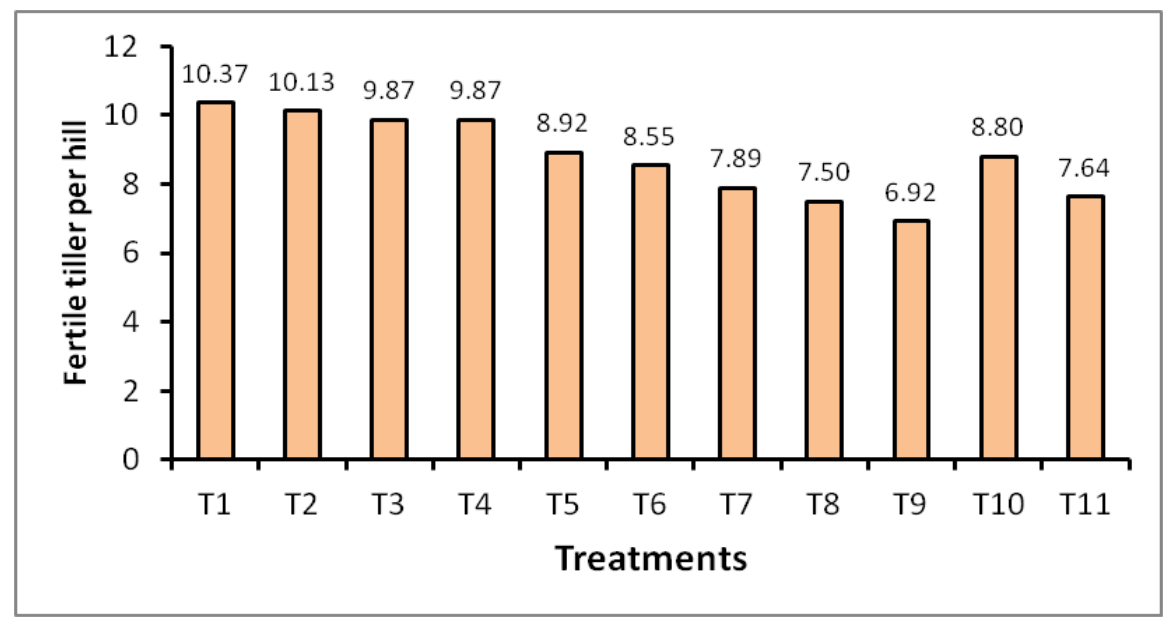

Fig. 2. Effect of critical period of rice weeds competition on effective tillers hill ${ }^{-}$ ${ }^{1}$ of transplant Aus rice cv. BRRI dhan27 $\left(\operatorname{LSD}_{(0.05)}=0.80\right)$

The highest (108.00) number of filled grains panicle ${ }^{-1}$ was recorded from the plots which were kept weed free for the total cropping duration. Plots which were weeded for the first time at 20 DAT and kept weed free for later on $\left(\mathrm{T}_{3}\right)$ showed the highest 1000- grain weight (31.58 g). The plots which were weeded only once at 20 and 40 DAT ( $\mathrm{T}_{10}$ and $\mathrm{T}_{11}$ ) showed similar effect (3.29 and 3. $28 \mathrm{tha}{ }^{-1}$ ) in terms of grain yield of BRRI dhan27. Percent grain yield reduction was increased with the increasing of weed competition period and it reached to the highest as $34.54 \%$ in unweeded control plots. In case of one weeding, weeding at 20 and 40 days after transplanting reduced the grain yield of about $17 \%$ of that of the weeded control plots. Weed free plots and the plots in which the competition of weed were allowed for first 10 , 20, 30 days and kept weed free for later on gave higher yield than others.

Grain yield of T. Aus rice cv. BRRI dhan27 was significantly affected by the treatments of weeding. The plots which were kept weed free from transplanting to harvesting gave the highest $\left(3.97 \mathrm{t} \mathrm{ha}^{-1}\right)$ grain yield and it was followed $\left(3.94 \mathrm{tha}^{-1}\right)$ by $\mathrm{T}_{2}$. The unwedded plots gave the lowest $\left(2.44 \quad \mathrm{t} \mathrm{ha}^{-1}\right)$ yield and it was followed by treatments (Table 4). When weed infestation is increased, the rice plants deprive from nutrient and other environmental components. As a result, the long time weed infested plot showed lower performance than short time weed infestation.

Table 4. Effect of duration of weed competition on the yield of transplant Aus rice cv. BRRI dhan27

\begin{tabular}{c|c|c|c|c}
\hline \multirow{2}{*}{ Treatments } & \multicolumn{2}{|c|}{ Grain yield } & \multicolumn{2}{c}{ Straw yield } \\
\cline { 2 - 5 } & $\mathrm{t} \mathrm{ha}^{-1}$ & \% reduction & $\mathrm{t} \mathrm{ha}^{-1}$ & \% reduction \\
\hline $\mathrm{T}_{1}$ & $3.97 \mathrm{a}$ & - & $3.22 \mathrm{ab}$ & - \\
$\mathrm{T}_{2}$ & $3.94 \mathrm{a}$ & 0.76 & $3.36 \mathrm{a}$ & -4.25
\end{tabular}


Rahman et al.

\begin{tabular}{ccccc}
$\mathrm{T}_{3}$ & $3.90 \mathrm{a}$ & 1.76 & $3.22 \mathrm{ab}$ & 0.00 \\
$\mathrm{~T}_{4}$ & $3.89 \mathrm{ab}$ & 2.02 & $3.09 \mathrm{ab}$ & 4.04 \\
$\mathrm{~T}_{5}$ & $3.76 \mathrm{~b}$ & 5.29 & $2.86 \mathrm{bc}$ & 11.18 \\
$\mathrm{~T}_{6}$ & $3.50 \mathrm{c}$ & 11.84 & $2.65 \mathrm{~cd}$ & 17.70 \\
$\mathrm{~T}_{7}$ & $3.05 \mathrm{e}$ & 23.17 & $2.53 \mathrm{~cd}$ & 21.43 \\
$\mathrm{~T}_{8}$ & $2.49 \mathrm{f}$ & 37.28 & $2.34 \mathrm{~d}$ & 27.33 \\
$\mathrm{~T}_{9}$ & $2.44 \mathrm{f}$ & 38.54 & $2.42 \mathrm{~d}$ & 24.84 \\
$\mathrm{~T}_{10}$ & $3.29 \mathrm{~d}$ & 17.13 & $2.65 \mathrm{~cd}$ & 17.70 \\
$\mathrm{~T}_{11}$ & $3.28 \mathrm{~d}$ & 17.38 & $2.57 \mathrm{~cd}$ & 20.19 \\
\hline LSD $_{(0.05)}$ & 0.13 & - & 0.42 & - \\
\hline
\end{tabular}

Weed population and their dry weight was increasing with the increasing of weed competition duration and weed removal delayed up to 60 days after transplanting and decreased thereafter. It might be due to death of some older weeds and thinning of newly germinated weeds. Unweeded control plots showed the poor result in case of maximum parameter where the grain yield reduced in the highest percentage (38.54\%). In case of grain and straw yield the plots which were allowed for 10 days weed competition $\left(T_{2}\right)$ showed the highest performance. Treatment $T_{2}$ gave better plant height (136.1), panicle length (23.90) and effective tillers hill ${ }^{-1}$ (10.13). On the other hand the plots in which competition of weed was allowed for first 20 days showed better performance in terms of total tillers hill ${ }^{-1}(10.82)$. In case of grain yield $\mathrm{T}_{1}$ (control), $\mathrm{T}_{2}$ (competition of weed for 10 days), $\mathrm{T}_{3}$ (competition of weed for 20 days) and $\mathrm{T}_{4}$ (competition of weed for 30 days) gave same and higher $\left(3.89-3.97 \mathrm{t} \mathrm{ha}^{-1}\right)$ yield than others.

\section{Conclusion}

The result obtained from the study showed that the percentage of grain yield reduction with the increasing of crop weed competition was negligible up to 30 days competition. So, crop weed competition for first 30 days could be a critical period in transplant Aus rice cv. BRRI dhan27.

\section{References}

Ahmed, S., A. Mamun, A. M. A. Islam and S. M. A. Hossain. 1986. Critical period of weed competition in transplanted Aus rice. Agric. Rev. 27: 247- 257.

Ahmed, S. and A. Majid. 1977. Effect of weed control duration on paddy yield of different varieties. J. Agric. Res. 15: 293-298.

Anonymous. 2003. Principles of Weed Management. International Rice Research Institute, P.O. Box.983. Manila, Philippines. p.113.

Baloch, M. S., I. U. Awan, S. A. Jatoi, I. Hussain and B. U. Khan. 2000. Evaluation of seeding densities in broadcast wet seeded rice. J. Pure Appl. Sci. 19: 63-65.

BRRI (Bangladesh Rice Research Institute). 2006. Weed identification and management in rice. Bangladesh Rice Res. Inst. Joydebpur, Gazipur, Bangladesh. pp.101-113.

Burnside, O. C., M. L. Wiens, B. J. Holder, S. Weisberg, E. A. Ristau, M. M. Johnson and J. H. Cameron. 1998. Critical period for weed control in dry beans (Phaseolus vulgaris). Weed Sci. 46: 301-306.

Chopra, N. K. and N. Chopra. 2003. Weed Management Strategy in Rice - A Review. Indian J. Weed Sci. 35: 27-29. 
Critical Period of Weed Competition in Transplant Aus Rice

Garrity, D. P., M. Morillion and K. Moody. 1992. Differential weed suppression ability in upland rice cultivars. Agron. J. 84: 586-591.

IRRI (International Rice Research Institute). 2006. Bringing hope, improving lives: Strategic Plan 2007-2015. Manila, Philippines. p.61.

Jennings, P. R. and R. C. Aquino. 1968. Studies on weed competition in rice. II. The mechanism of competition among phenotypes. Evolution. 22: 529-542.

Johnson, D. E. 2002. Weed management in small holder rice production in the tropics. Chatham, Kent, UK: Natural Resources Institute, University of Greenwich.

Kabir, H. 2006. Adaptation and adoption of the system of rice intensification in Myanmar using the Farmer Field School (FFS) approach. Available: http://ciifad.cornell.edu/sri/theses/kabirthesis. pdf.

Karim, S. M. R. 2000. Competitive ability of three grass weeds grown in upland direct-seeded rice in Bangladesh. Pakistan J. Agric. Res. 16: 24-27.

Khush, G. S. 2005. What it will take to feed 5.0 billion rice consumers in 2030. Plant Mol. Biol. 59: 1-6.

Mamun, A. A., S. Ahmad and A. U. Sarker. 1986. Critical period of crop weed competition in direct-seeded Aus rice. Bangladesh J. Agric. Sci. 13: 61-66.

Mercado, B. L. 1979. Introduction to weed science. Southeast Asian Regional Center for Graduate Study and Research in Agriculture, Laguna, PhiliPpines. p.292.

Mukherjee, D. and R. P. Singh. 2003. In: Proc. Biennial Conf. of Indian Soc. Weed Sci. held at Pant Nagar from 12-14, March, p.11.

Mukherjee, D. and R. P. Singh. 2005. Weed Management Strategy in Rice. Indian J. Agron. 50: 194-196.

Perera, K. K., P. G. Ayres and H. P. M. Gunasena. 1992. Root growth and the relative importance of root and shoot competition in the interactions between rice (Oryza sativa) and E. crusgalli. Weed Res. 32: 6776.

Sarker, M. Y., M. M, Hossain, M. K. Hasan, M. A. H. Khan, M. R. Amin and F. Begum. 2002. Weed infestation in direct seeded and transplanted Aus rice as affected by method of planting and weeding regime. J. Biol. Sci. 2: 652-655.

Singh, O. P. and V. M. Bhan. 1988. Chemical weed control in lowland transplanted rice under puddle condition. Indian J. Weed Sci. 18: 244-249.

SRDI (Soil Resource Development Institute). 2005. Upozilla Nirdeshika: Dumki (in Bengali). $2^{\text {nd }}$ edn. Dhaka, Bangladesh. pp.7-87.

Sultana, R. 2000. Competitive ability of wet seeded boro rice against E. crusgalli and E. colonum. M. S. Thesis BAU, Mymensingh, Bangladesh. pp. 36-50.

Zhang, Ze-Pu. 1996. Weed management in transplanted rice. In: B. A. Auld and K. U. Kim (Eds.) Weed Management in Rice. FAO Plant production and Protection paper 139. Food and Agriculture Organization of the United Nations, Rome, Italy. 